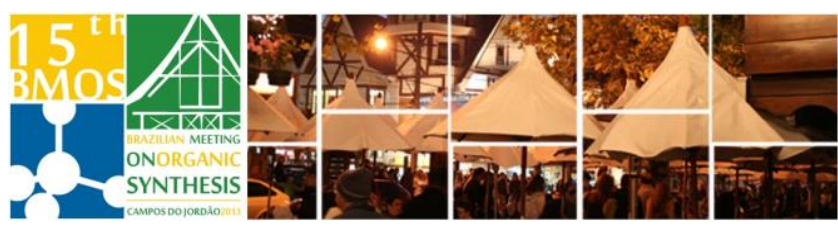

\title{
New 1,3,4-Oxadiazolyl-pyrazolyl-Pyridine Tricyclic Scaffold Derivatives: Synthesis and Structure Assignment by NMR and DFT Calculations
}

\author{
Gisele R. Paim (PQ) ${ }^{*}$, Susiane C. Meira (PG) ${ }^{2}$, Everton P. Pittaluga (PG) ${ }^{2}$, Liliane M. \\ F. Porte $(P Q)^{2}$, Alexandre R. Meyer $(P G)^{2}$, Jussara Navarini $(P Q)^{3}$, Helio $G$. \\ Bonacorso (PQ) ${ }^{2}$. \\ ${ }^{1}$ Instituto Federal Farroupilha - Campus Júlio de Castilhos 98130-000, Júlio de Castilhos, RS. \\ ${ }^{2}$ Núcleo de Química de Heterociclos (NUQUIMHE), Departamento de Química, Universidade Federal de \\ Santa Maria 97015-900, Santa Maria, RS. \\ ${ }^{3}$ Instituto Federal Farroupilha - Campus Alegrete 97555-000, Alegrete, RS. \\ *gi_quimica@jc.iffarroupilha.edu.br:
}

Keywords: 1,3,4-oxadiazoles, pyridine, DFT calculations

\section{INTRODUCTION}

Among five-membered aromatic heterocycles, 1,3,4oxadiazoles are important class of aromatic heterocycles displaying a broad spectrum of biological activities, such as antimicrobial, antiinflammatoy, analgesic, anticonvulsivant, antihypoglycemic. ${ }^{1}$ Compounds containing oxadiazole moieties have been described as possessing anticancer or muscle relaxant activity and have been used as fluorescent whiteners. ${ }^{2}$ Usually, the synthesis of non-symmetrical 2,5-disubstituted 1,3,4oxadiazoles has mainly been done by dehydratation of diacylhydrazines or oxidative cyclization of aldehyde $N$-acylhydrazones, but many other reagents and reaction conditions have been reported to achieve their obtainment. ${ }^{3}$

\section{RESULTS AND DISCUSSION}

Following our previous work ${ }^{4}$ and in attempting to introduce another class of nitrogenated azoles into the pyrazolyl-pyridine system, compounds methyl 6-[alkyl/aryl-5-trifluoro-methyl-1 $H$-pyrazol-1yl]nicotinate hydrochloride $1 \mathbf{a}-\mathbf{b}$ were reacted firstly with hydrazine hydrate under reflux of ethanol to give the hydrazides of $\mathbf{2} \mathbf{a}-\mathbf{b}$. These hydrazides were submitted to a cyclocondensation reaction with $\mathrm{R}^{1} \mathrm{C}(\mathrm{OEt})_{3}(\mathbf{3})$, where $\mathrm{R}^{1}=$ methyl (3a) and phenyl (3b), leading to the obtention of four examples of oxadiazolyl-pyrazolyl-pyridines (4aa-bb), at moderate yields (Scheme 1). As the reaction property, the orthoesters were used simultaneously as solvent and reagent and compounds of 4 aa-bb precipitated steadily during the reaction time at $110^{\circ} \mathrm{C}$. Compounds 4 aa-bb were characterized by ${ }^{1} \mathrm{H}$ and ${ }^{13} \mathrm{C}$ NMR spectroscopy and thus, in order to assign the conformation of the oxadiazolyl-pyrazolylpyridines (4) we employed theoretical calculations using the Density Functional Theory (DFT) method. ${ }^{5}$

\section{CONCLUSION}

To demonstrate the applicability of the esters $\mathbf{1}$, new hydrazides 2 and their oxadiazolyl-pyrazolylpyridines $\mathbf{4}$ were able to be produced as a new triheterocyclic scaffold at moderate yields.

\section{ACKNOWLEDGEMENTS}

Instituto Federal Farroupilha- Campus Júlio de Castilhos, UFSM, CAPES, CNPq

\section{REFERENCES}

${ }^{1}$ (a) Gaonkar, S. L.; Rai,. K. M. L.; Prabhuswamy, B. Eur J Med Chem 2006, 41, 841. (b) Macaev, F.; Rusu, G.; Pogrebnoi, S.; Gudima, A.; Stingaci, E.; Vlad, L.; Shvets, N.; Kandemirli, F.; Dimoglo, A.; Reynolds, R. Bioorg Med Chem 2005, 13, 4842.(c) Zheng, X.; Li, Z.; Wang, Y.; Chen, W.; Huang, O.; Liu, C.; Song, C. J Fluorine Chem 2003, 123, 163.

${ }^{2}$ Bhatt, J. J.; Shah, B. R.; Shah, H. P.; Trivedi, P. B.; Undavia, N. K.; Desai, N. C. J Indian Chem 1994, 33B, 189.

(a) Weaver, G. W. In Science of Synthesis; Storr, R. C.; Gilchrist, T. L., Eds.; Thieme: Stuttgart, 2004; 13, 219; (b) Hill, J.. In Comprehensive Heterocyclic Chemistry II; Storr, R. C., Ed. Pergamon, Oxford, 1996; 4 267 and 905 (c) Dobrotã, C.; Paraschivescu, C. C.; Dumitru, I.; Matache, M.; Baciu, I.; Rutã, L. L. Tetrahedron Lett 2009, 50, 1886 and references therein

${ }^{4}$ Bonacorso, H. G.; Paim, G. R.; Porte, L. M. F.; Pittaluga, E. P.; Martins, M. A. P., Zanatta, N. ARKIVOC 2012, viii, 214

${ }^{5}$ Gaussian 09, Revision A.1, Frisch, M. J. et all Gaussian, Inc., Wallingford CT, 2009.<smiles>[R]c1cc(C(F)(F)[In])n(-c2ccc(C(=O)OC)cn2)n1</smiles>

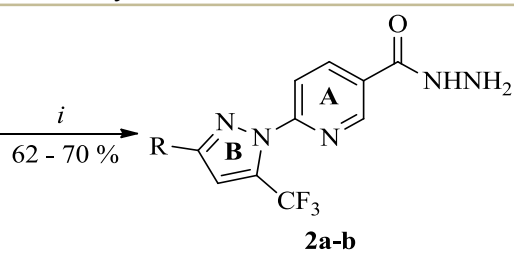<smiles>CC(C)C#CC(C)C</smiles><smiles>[R]c1cc(C(F)(F)F)n(-c2ccc(-c3nnc([R])o3)cn2)n1</smiles>

Scheme 1. Reagentes and conditions: (i) $\mathrm{NH}_{2} \mathrm{NH}_{2} \cdot \mathrm{H}_{2} \mathrm{O}$, EtOH, reflux, $20 \mathrm{~h}$; (ii) (3) $\mathrm{R}^{1} \mathrm{C}(\mathrm{OEt})_{3}, 110{ }^{\circ} \mathrm{C}, 16 \mathrm{~h}$. $\mathrm{R}=\mathrm{Me}, \mathrm{Ph} ; \mathrm{R}^{1}=\mathrm{Me}, \mathrm{Ph}$. $15^{\text {th }}$ Brazilian Meeting on Organic Synthesis - 15 ${ }^{\text {th }}$ BMOS - November 10-13, 2013 - Campos do Jordão, Brazil 